\title{
Evaluating revegetation practices for sandy cropland in the Nebraska Sandhills
}

\author{
S. OLDFATHER, J. STUBBENDIECK, AND S.S. WALLER
}

\begin{abstract}
Supplemental irrigation generally increased seedling density the seeding year; however, this response was not maintained the year following seeding. Above-average precipitation minimized the importance of irrigation the seeding year. Seeding mixture appeared important with a 6- and 4-species mixture providing better establishment than a 2-species mixture. This was apparently due to the relatively large proportion of switchgrass (Panicum virgatum $\mathbf{L}$.) in the 2-species mixture and its generally poor establishment. The reduced seeding rate resulted in better stand establishment than the recommended rate on a tilled seedbed (1.1 and 0.7 seedlings/0.1 $\mathrm{m}^{2}$, respectively), while neither seeding rate provided an acceptable stand ( 0.5 seedlings $/ 0.1 \mathrm{~m}^{2}$ ) with the no-till treatment in small plot evaluations. Seedbed tillage also resulted in a higher seedling density than no-tlllage ( 1.3 and 0.5 seedlings $/ 0.1 \mathrm{~m}^{2}$, respectively) for the production-level field trial. Seedling density was doubled with depth bands $\left(1.2 \mathrm{vs}\right.$. 0.6 seedlings $\left./ 0.1 \mathrm{~m}^{2}\right)$. These results suggested that a tilled seedbed on sandy cropland with adequate moisture results in successful stands. A native, warm-season grass mixture ( 4 or more species) is recommended with a seeding rate of 15 PLS/0.1 $\mathrm{m}^{2}$ using equipment with depth bands.
\end{abstract}

Key Words: seeding, warm-season grasses, seeding rate, seedbed preparation, tillage

Native vegetation of the Nebraska Sandhills is a mixture of short, mid-, and tall grasses (Pool 1914). Soils are sandy, low in organic matter, highly erosive, and have high infiltration rates. Rising prices for corn (Zea mays $L$.) and development of sprinkler irrigation systems during the 1970's accelerated conversion of Sandhills rangeland to cropland. More recently, reduced crop yields, low prices, and rising fuel costs have contributed to abandonment of Sandhills cropland, which has increased soil eroison potential in the region.

Seeding rate is a major factor influencing revegetation costs. Seeding rate recommendations of 20 to $40 \mathrm{PLS} / 0.1 \mathrm{~m}^{2}$ are common for warm-seeded grasses (Vogel 1987). Launchbaugh and Owensby (1970) seeded native, warm-season species in Kansas at 4, 13,40 , and $120 \mathrm{PLS} / 0.1 \mathrm{~m}^{2}$. A seeding rate of $13 \mathrm{PLS} / 0.1 \mathrm{~m}^{2}$ was required to meet minimum stand density requirements $(0.5$ seedlings $/ 0.1 \mathrm{~m}^{2}$ ). Seeding rates of $10 \mathrm{PLS} / 0.1 \mathrm{~m}^{2}$ may be sufficient in some years, particularly if plantings are to be used as a conservation practice rather than grazed (Vogel 1987).

Control of weeds is another factor affecting seeding success. Spring tillage with a disk has been successful prior to seeding crested wheatgrass [Agropyron desertorum (Fisch. ex Link) Schult.] when downy brome (Bromus tectorum L.) was prominent (Evans and Young 1987). However, tilled seedbeds have not been

Authors are district conservationist, Soil Conservation Service, Elwood, Nebr. 68937; and professors, Department of Agronomy, University of Nebraska, Lincoln 68583. At the time of the research, the senior author was research technologist, Department of Agronomy, University of Nebraska-Lincoln.

Authors wish to thank Dr. Peter DeMarco for providing land for the research. Mention of the proprietary name does not constitute endorsement by the Nebraska Agricultural Research Division. Published as Paper No. 8641, Jour. Ser., Nebraska Agricultural Research Division.

Manuscript accepted 6 September 1988. recommended in the Great Plains due to high wind erosion potential (Barnes et al. 1952).

Seedlings established with irrigation were more vigorous and productive than dryland seedlings in southeastern Montana (Depuit et al. 1982). Conversely, watering did not affect stand densities of warm-season grasses during the establishment year in North Dakota (Ries and Hofmann 1987).

Objectives of the study were to evaluate and compare various warm-season grass mixtures, seeding rates, effect of tillage on weed control, depth of planting, and irrigation on grass establishment in the Nebraska Sandhills.

\section{Materials and Methods}

\section{Study Area}

The investigation was carried out on a terrace of the Middle Loup River in Custer County, Nebraska. The 76-ha site was a complex of Ipage (mixed, mesic Aquic Ustipsamment) and Valentine (mixed, mesic Typic Ustipsamment) soils. Both soils are sandy, have high infiltration rates, low organic matter, and low water holding capacity and are classified as sandy lowland or sandy range sites. Frost free days range from 110 to 142 . Annual precipitation averages $57 \mathrm{~cm}$ with $80 \%$ occurring between April and September (Wilson et al. 1982).

The area was native range until 1971 when it was plowed and a center-pivot irrigation system was installed. Corn was produced until 1980 when sorghum/sudangrass [Sorghum bicolor (L.) Moench] hybrid was seeded in May, 1981. Crop residue remained on the site in 1982.

Replication of abandoned center-pivot sites is not generally feasible. Consequently, this study was designed as a series of small plot and field (production-level) screening trials with treatments replicated within 1 center-pivot site. The center pivot irrigation system nozzling configuration was redesigned to deliver 6 strips (each $60 \mathrm{~m}$ wide) of water (0, x, 2x levels, replicated twice). A replication for irrigation consisted of 3 adjacent strips with each irrigation level randomly assigned. The center pivot site was divided into 2 blocks based on the 2 major soils. Each block ( $38 \mathrm{ha}$ ) was divided in half, and a different tillage treatment, single disking no-till, was randomly assigned. Tillage was completed 6 May 1982. Experimental design was a randomized complete block replicated twice with a strip-split-split treatment arrangement (Cochran and Cox 1957). Irrigation amount was the whole plot and tillage treatment was the subplot for both small plot and field studies. Sub-sub plots varied by experiment.

Spring precipitation the year of seeding was above average. April $(6.7 \mathrm{~cm})$, May $(14.0 \mathrm{~cm})$, and June $(8.8 \mathrm{~cm})$ were $30 \%$ above average. July $(2.2 \mathrm{~cm})$ and September $(1.7 \mathrm{~cm})$ precipitation was deficient, while August precipitation $(11.2 \mathrm{~cm})$ was above average (NOAA 1982). Water was applied $14 \mathrm{July,} 19 \mathrm{July}$, and 5 August 1982, for a total application of 0,2 , and $4 \mathrm{~cm}$ for the 3 irrigation levels. Irrigation was not needed prior to July; however, equipment malfunction did not allow optimum irrigation during a dry period in July of the establishment year or repetition of the study the 
EXAMPLE OF SEED MIXTUAES RATES

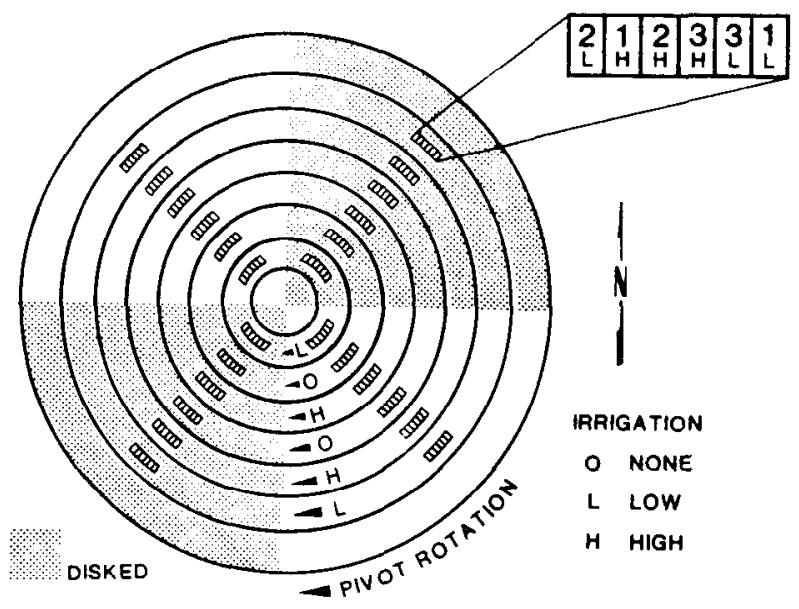

Fig. 1. Schematic drawing of research site and treatments.

subsequent year. Irrigation was not continued in 1983. Dormant season (October 1982-March 1983) precipitation was $20.5 \mathrm{~cm}$ above average, and the growing season (April-September) precipitation was $12.4 \mathrm{~cm}$ above average (NOAA 1983).

\section{Small Plot Trial}

Within each block*tillage*irrigation level combination, plots $(8$ $\times 18 \mathrm{~m}$ ) were established to evaluate establishment of seeding mixtures and seeding rates. Plots were located in the center of each irrigation strip and divided into 6 small sub-plots $(8 \times 3 \mathrm{~m})$ (Fig. 1). Three mixtures were seeded at 2 rates (sub-sub plot) (Table 1) May 23,1982 in a factorial arrangement using a Tye 'Pasture Pleaser' drill with a row spacing of $25 \mathrm{~cm}$ and a planting depth of $2.5 \mathrm{~cm}$.

\section{Field Trial}

Within each block, tillage treatments were divided in half and each half was randomly assigned 1 of 2 drills to evaluate the importance of soil depth bands (sub-sub plots) during seeding. A Tye 'Pasture Pleaser' was equipped with coulter blades and double disc openers; however, depth bands were removed. A Truax drill with a row spacing of $25 \mathrm{~cm}$ and double disc openers was used with depth bands set at $2.5 \mathrm{~cm}$. The entire center-pivot site, excluding those plot areas used in the small plot trial, was seeded with mixture 1 at $21 \mathrm{PLS} / 0.1 \mathrm{~m}^{2}$ in late May 1982.

\section{Sampling and Experimental Design}

Seedling density was recorded during September 1982 and August 1983 using ten $0.1-\mathrm{m}^{2}$ frames placed randomly in each small plot $(8 \times 3 \mathrm{~m})$. The field trial was sampled on the same dates using 20 frames within each block*irrigation level*tillage*depth band experimental unit. A seeding failure was defined as $<0.5$ seedlings/ $0.1 \mathrm{~m}^{2}$ (Launchbaugh 1966).

\section{Results}

\section{Small Plot Trial}

The disked seedbed was analyzed separately from no-till due to a higher proportion of zero values in no-till plots resulting in nonhomogeneity of variance. Seedling density increased with irrigation $(P=0.02)$ on the disked seedbed the seeding year; however, irrigation had no influence on density in 1983. Irrigation failed to influence seedling density on the no-till seedbed in either year.

A Bartlett's test of homogeneity of variance (Steel and Torrie 1980) indicated that the variance of mixture 3 was probably not equal to the variance of mixtures 1 and 2 . Transformations were
Table 1. Seeding mixtures and seeding rates used for intensive plot trial.

\begin{tabular}{|c|c|c|}
\hline \multirow[b]{2}{*}{ Mixture/species } & \multicolumn{2}{|c|}{ Seeding rate } \\
\hline & Normal & Reduced \\
\hline & \multicolumn{2}{|c|}{$-\mathrm{PLS} / 0.1 \mathrm{~m}^{2}$} \\
\hline $\begin{array}{l}\text { 1:Six-species mixture } \\
\text { Little bluestem } \\
\text { Schizachyrium scoparium (Michx.) Nash }\end{array}$ & 4.3 & 2.5 \\
\hline $\begin{array}{l}\text { Prairie sandreed } \\
\text { Calamovilfa longifolia (Hook.) Scribn. }\end{array}$ & 4.3 & 2.5 \\
\hline $\begin{array}{l}\text { Sand bluestem } \\
\text { Andropogon gerardii var. paucipilus (Nash) } \\
\text { Fern. }\end{array}$ & 5.4 & 3.0 \\
\hline $\begin{array}{l}\text { Sand lovegrass } \\
\text { Eragrostis trichodes (Nutt.) Wood }\end{array}$ & 2.8 & 1.6 \\
\hline $\begin{array}{l}\text { Indiangrass } \\
\quad \text { Sorghastrum nutans (L.) Nash }\end{array}$ & 2.2 & 1.2 \\
\hline $\begin{array}{l}\text { Switchgrass } \\
\quad \text { Panicum virgatum } \mathrm{L} \text {. }\end{array}$ & 2.2 & 1.7 \\
\hline Total & 21.2 & 12.5 \\
\hline $\begin{array}{l}\text { 2:Four-species mixture } \\
\text { Little bluestem } \\
\text { Prairie sandreed } \\
\text { Sand bluestem } \\
\text { Sand lovegrass }\end{array}$ & $\begin{array}{r}3.8 \\
4.3 \\
6.6 \\
12.3 \\
\end{array}$ & $\begin{array}{l}2.8 \\
2.2 \\
3.4 \\
6.9 \\
\end{array}$ \\
\hline Total & 27.0 & 15.3 \\
\hline $\begin{array}{l}\text { 3:Two-species mixture } \\
\text { Sand lovegrass } \\
\text { Switchgrass }\end{array}$ & $\begin{array}{r}6.0 \\
15.4 \\
\end{array}$ & $\begin{array}{l}3.7 \\
9.9\end{array}$ \\
\hline Total & $\overline{21.4}$ & 13.6 \\
\hline AVERAGE TOTAL & 23.2 & 14.0 \\
\hline
\end{tabular}

not successful; therefore, seeding mixtures were not compared. However, seeding mixtures 1 and 2 were similar and averaged 1.1 and 0.3 seedlings $/ 0.1 \mathrm{~m}^{2}$ on the tilled and no-tilled seedbeds, respectively. Mixture 3 failed $(>0.5)$ seedlings $/ 0.1 \mathrm{~m}^{2}$ in all treatment combinations.

Seeding rate*irrigation rate and seeding rate*seeding mixture interactions were not statistically significant. Consequently, the effect of seeding rate averaged over irrigation levels and seeding mixtures was evaluated within each tillage treatment (Table 2). The

Table 2. The effect of seeding rate on seedling density (seedlings/0.1 $\mathrm{m}^{2}$ ) averaged over 3 warm-season grass mixtures seeded in tilled and no-till seedbeds in May, 1982.

\begin{tabular}{|c|c|c|}
\hline \multirow[b]{2}{*}{ Treatment } & \multicolumn{2}{|c|}{ Seedling density } \\
\hline & September 1982 & August, 1983 \\
\hline & \multicolumn{2}{|c|}{ _____seedlings $0.1 \mathrm{~m}^{2}$} \\
\hline $\begin{array}{l}\text { Tilled seedbed } \\
\text { Normal seeding rate } \\
\text { Reduced seeding rate }\end{array}$ & $\begin{array}{l}0.7 \\
1.1\end{array}$ & $\begin{array}{l}0.6 \\
0.8\end{array}$ \\
\hline $\mathbf{P}>\mathbf{F}$ & 0.01 & 0.03 \\
\hline $\begin{array}{l}\text { No-till seedbed } \\
\text { Normal seeding rate } \\
\text { Reduced seeding rate }\end{array}$ & $\begin{array}{l}0.3 \\
0.2\end{array}$ & $\begin{array}{l}0.2 \\
0.2\end{array}$ \\
\hline $\mathbf{P}>\mathbf{F}$ & 0.65 & 0.14 \\
\hline
\end{tabular}

reduced seeding rate was superior to the normal seeding rate on the tilled seedbed. The reduced rate resulted in greater seedling emergence during the seeding year and also provided greater seedling density the following year. Stands failed with both seeding rates on 
the no-till treatment. Although seedbeeds in the small plot study could not be statistically compared, seedling densities were numerically higher for the tilled seedbed both years.

\section{Field Trial}

Interactions were not detected between supplemental irrigation, tillage, and depth band treatments; therefore, each factor was analyzed independently. Supplemental irrigation (averaged over tillage and depth band treatments) increased seedling density $(P=$ $0.10)$ the seeding year. Both levels of supplemental water ( $x$ and $2 x)$ averaged 1 seedling $/ 0.1 \mathrm{~m}^{2}$ while the control had 0.7 seedlings $/ 0.1$ $\mathbf{m}^{2}$. The response to supplemental water was not evident the year following seeding.

The field trial verified observations in the small plot study. The tilled seedbed had greater seedling density than did the no-till seedbed during the year of seeding (Table 3 ). Little change

Table 3. The effect of seedbed tillage and use of depth bands on drills on seedling density of a warm-season grass mixture seeded (21 PLS 0.1 m²) in May, 1982.

\begin{tabular}{llc}
\hline \hline & \multicolumn{2}{c}{ Seedling density (seedlings $0.1 \mathrm{~m}^{2}$ ) } \\
\cline { 2 - 3 } Treatment & September 1982 & August, 1983 \\
\hline Seedbed & 1.3 & 1.3 \\
Tilled & 0.5 & 0.7 \\
No-till & 0.07 & $<0.01$ \\
$\quad$ P $>$ F & & \\
Drill & & \\
With depth bands & 1.2 & 1.4 \\
Depth bands removed & 0.6 & 0.6 \\
P $>$ F & 0.09 & 0.01 \\
\hline
\end{tabular}

occurred in stand density due to overwintering. The no-till seedbed had marginal stands during the first year; however, there appeared to be some improvement in the second year.

The use of depth bands increased seedling establishment (Table 3). Areas seeded with depth bands had twice the seedling emergence and second year establishment than areas seeded without depth bands.

\section{Discussion and Conclusions}

While this study suggested that supplemental water only provided a temporary effect, above-normal precipitation during the seeding year and problems associated with timing and amount of irrigation confounded the effect. Timely irrigation at appropriate levels is likely to be more important in normal to dry years resulting in better stand establishment.

Switchgrass represented approximately $70 \%$ of mixture 3 while it was only $10 \%$ of mixture 1 . Switchgrass exhibited poor emergence. Sandbur [Cenchrus longispinus (Hack.) Fern.] was the prominent weed on the tilled treatment during the seeding year (Kocher and Stubbendieck 1986). Roder et al. (1988) determined that alleopathy attributed to sandbur reduced switchgrass emergence. Sandbur control may be necessary when switchgrass is placed into a tilled seedbed.

Seedling establishment from the reduced seeding rate was superior to that of the normal seeding rate on the tilled seedbed. Excluding mixture 3, the reduced seeding rate resulted in a successful stand ( 1 plant $/ 0.1 \mathrm{~m}^{2}$ ), supporting other research (Launchbaugh and Owensby 1970). A reduced seeding rate (11 PLS $\left./ 0.1 \mathrm{~m}^{2}\right)$ produced less dense, but acceptable, stands compared to higher seeding rates for big bluestem (Andropogon gerardii var. gerardii Vitman) and switchgrass when weed control was adequate (Vogel 1987). Use of lower seeding rates would be dependent on manage- ment goals. Conservation plantings or pasture plantings that will be minimally grazed during the first 2 to 3 years of establishment may be seeded at lower rates.

Greater seedling densities were produced on tilled plots than on plots receiving no seedbed preparation. Disking provided a clean seedbed at the time of seeding; however, it also stimulated a large increase of sandbur to compete with the grass seedlings compared to the no-till. Weed competition on no-till plots was less; however, the seedbed lacked firmness. Unlike finer textured soils, tillage of these sandy soils caused a firmer, more settled seedbed compared to no-till seedbeds which have been fallowed. The firmer seedbed also allowed more uniform seed placement with and without depth bands. A clean-tilled seedbed may not have been as beneficial in years when moisture was limiting due to moisture competition from weeds. Since soil moisture was adequate during the establishment year, seedlings could compete with sandbur on the tilled seedbed. King (1987) reported a stand failure on a dryland seeding, primarily due to sandbur competition, while an irrigated site the same year had a successful stand even though total weed competition was greater.

Seeding depth is difficult to control on sandy seedbeds that have been out of production several years. Drills with and without depth bands produced stands that were minimally acceptable $(0.5$ seedlings $/ 0.1 \mathrm{~m}^{2}$ ). However, drill availability should not encourage the use of equipment without depth bands. Sandy soils of idle cropland in the Sandhills are often soft, making shallow seeding difficult and increasing seed zone desiccation. These conditions require tillage prior to seeding and use of depth bands.

\section{Literature Cited}

Barnes, O.K., R.L. Lang, and A.A. Beetle. 1952. Grass establishment on Wyoming dryland. Wyoming Agr. Exp. Sta. Bull. 314.

Cochran, W.G., and G.M. Cox. 1957. Experimental designs. Wiley Publications, New York.

Depuit, E.J., C.L. Skilbred, and J.G. Coenberg. 1982. Effects of two years of irrigation on revegetation of coal surface-mined land in southeastern Montana. J. Range Manage. 35:67-73.

Evans, R.A., and J.A. Young. 1987. Seedbed modification with weed control and seeding. p. 52-56. In: G.W. Frasier and R.A. Evans (eds.) Proc. Sym. Seed and Seedbed Ecology of Rangeland Plants. USDA/ARS.

King, M.A. 1987. Establishment of forage grasses on abandoned Sandhills cropland. M.S. Thesis, Univ. of Nebraska-Lincoln.

Kocher, E., and J. Stubbendieck. 1986. Broadcasting grass seed to revegetate sandy soils. J. Range Manage. 39:555-57.

Launchbaugh, J.L. 1966. A stand establishment survey of grass plantings in the Great Plains. Nebraska Agr. Exp. Sta. Great Plains Counc. Pub. 23.

Launchbaugh, J.L., and C.E. Owensby. 1970. Seeding rate and first year stand relationships for six native grasses. J. Range Manage. 23:414-417.

National Oceanic Atmospheric Administration. 1982. Climatological data, Nebraska. U.S. Dep. of Comm. Environmental Data Inf. Ser. Asheville, North Carolina.

National Oceanic Atmospheric Administration. 1983. Climatological data, Nebraska. U.S. Dep. of Comm. Environmental Data Inf. Ser. Asheville, North Carolina.

Pool, R.J. 1914. A study of the vegetation of the Sandhills of Nebraska. Minnesota Bot. Stud. 4:189-312.

Ries, R.E., and L. Hofmann. 1987. Environment and water pattern override amount for grass establishment in North Dakota. p. 199-201. In: G.W. Frasier and R.A. Evans (eds.) Proc. Sym. Seed and Seedbed Ecology of Rangeland Plants. USDA/ARS.

Roder, W., S.S. Waller, and J. Stubbendieck. 1988. Allelopathic effects of sandbur leachate on switchgrass germination: observations. J. Range Manage. 41:86-87.

Steel, R.G.D., and J.H. Torrie. 1980. Principles and procedures of statistics. McGraw-Hill Book Co., New York.

Vogel, K.P. 1987. Seeding rates for establishing big bluestem and switchgrass with preemergence atrazine applications. Agron. J. 79:509-512.

Wilson, J.R., W. Vaneck, J. Carlson, B. Koepke, R. Zink, G.A. Bowman, C. Brown, L. Sherfey, C.C. Cotter, and H. Schultz. 1982. Soil survey of Custer County, Nebraska. USDA/SCS. 